\title{
Forum
}

\section{Teaching Metaphors of Politics to Overcome Students' Dislike of Politics}

Nearly every experience in my short teaching career confirms Bennett's (1997) argument that today's students dislike politics and mistrust political leaders. He $(1997,52)$ calls for "balance" in the classroom to combat a deepening cynicism in our young citizens.

I find myself criticizing American politicians and our national, state, and local institutions, not praising them.... We in political science ought, at least occasionally, to draw our students' attention to those aspects of the American Constitution, political system, and even our political leaders that merit praise.

One way to tackle this problem is discuss it immediately in the first class session. I start introductory American government classes by asking three questions: How many in the class read a newspaper yesterday? How many know the name of the Chief Justice of the Supreme Court? How many like politics? After less than five hands go up after each question, we establish that the class does not pay attention to politics, does not know much about politics, and does not even like politics.

Then I ask the students to tell me why they do not like politics. I put a list of their answers on the board. I get the same answers each time: Politicians are corrupt and in it for themselves; We can't do anything to change the system; Politics is boring and confusing; All they do is argue and sling mud; They never solve any problems; Politics does not affect my life.

I then argue that the class has these criticisms of politics because they interpret our political system with a particular metaphor: politics as a game. They do not interpret politics with a competing metaphor: politics as a conversation. The game metaphor includes the following assumptions:

1) Politics is a game that others play.

2) The object is to win.

3) The players of the game are either winners or losers.

4) Players are constantly worried about who is ahead and who is behind.

5) The rules are static.

The conversation metaphor includes these competing assumptions.

1) Politics is a conversation in which we all take part.

2) The object is to solve problems.

3) The participants in the conversation are citizens.

4) Citizens debate the merits of the arguments.

5) The rules are dynamic.

I always marvel at how easy it is to convince students that they do not like politics because they use the game metaphor. As the course unfolds I use these metaphors to structure the vast array of topics in an American government class. Unfortunately, much of our politics supports the game metaphor: candidatecentered elections, the unending horse race stories in the media, narrow special interest groups, and bureaucracies protecting their budgets, for instance. Actors in our political system often seem to be trying to win the game, or manipulating the system for their own purposes.

It is difficult to convince students that the conversation metaphor is a plausible interpretation of our political system. If politics is a conversation, then the essence of politics is the evaluation of arguments. I try as often as I can to characterize politics as the evaluation of arguments: citizens must evaluate the competing arguments of the parties and individual candidates; members of Congress must evaluate the competing arguments of interest groups; and presidents must evaluate the competing arguments of their advisers. But stu- dents tend to believe - as we all do at times-that these decisions are intended to maximize re-election chances more often than to solve problems.

It is even more difficult to convince students that these metaphors are self-fulfilling prophecies. If students believe that politics is a game that others play and that they cannot change the rules, then that is precisely the political system they will get. As long as we disdain politics and blame "Washington," no one has the incentive to change the system. Within the conversation metaphor, it is everyone's fault if the system is really as bad as they believe it is. And if politics is a conversation, it is within everyone's power to change the system.

I try to challenge the students throughout the semester by using the conversation model. They must come up with ideas to reform the system to make it more like a conversation. We discuss term limits, campaign finance reform, a balanced budget amendment, universal registration, direct techno-democracy, and other possibilities that may or may not improve our politics. The cynicism that creeps into all our teaching, the cynicism that Bennett warns us about, essentially conveys the metaphor that politics is a game. It reinforces students' feelings of helplessness and alienation. Emphasizing the metaphor that politics is a conversation is one way to present the "balance" called for by Bennett.

\section{References}

Bennett, Steven E. 1997. "Why Young Americans Hate Politics, and What We Should Do About It," PS, 30(1): 47-52.

Brian Frederking Syracuse University 


\section{Talking Tenure}

I was interested by the discussion of the institution of tenure in the March issue. Some days I'm for it, and some days I'm against it, but I would like to voice a few points that were, at most, alluded to in the $P S$ forum.

First, I should be clear about my position. I returned to graduate school after 25 years of "doing" politics and am finishing my dissertation. I am in my second year of teaching, have a tenure-track position, and anticipate being able to achieve tenure-if I can continue squelching some of my personal beliefs and characteristics so that I appear to meet the norms of the university community.

This is where my problem with the tenure system arises. From my first months in graduate school, I was told to "keep quiet" if I wanted a degree and, eventually, tenure. Apparently, my views are controversial in the profession primarily because my research is about issues involving Native Americans, which are highly normative and politically chargedespecially in this part of the country.

The pressure to "be quiet" is also, I believe, stronger for females. Women have generalized views on life that are different from men's, and we are in a male-dominated profession. This makes us consistently norm-suspect. I have gone through graduate school and entered this profession as a single parent. I have had many of the undersirable experiences that are common to women in this country, but are less common or unknown to men. I also have experiences as a faculty member that males do not face-the confused student who couldn't find "Mr. Jones" in my office; the repeated assumption that I'm the department secretary if $I$ happen to be in the department office. Naturally, these things affect my life views. To the extent that my life views are different from those of the men who will judge my professional output, I am at a disadvantage.

In my case, there is an additional factor that most students and new instructors do not face. I had a lot of political experience before I entered graduate school. I am probably more aware than most of the political forces affecting this profession and my life in it. But my political experience also taught me to pick my fights. Despite my feelings, I have gone about the business of doing the best I can to contribute to the profession and the support of my family, maintaining high professional standards for my research, teaching, and service activities.

The overall problem for the profession is that the tenure system stifles difference and, thus, stifles innovation-both within the discipline and in the policy-making arenas that our graduates influence. If our profession's initiates must "be quiet" for 12 years of graduate school and teaching, we are likely to get professionals who are habituated to docile behavior. Twelve years is a long time-the same amount that most of us went to elementary and secondary school, which was plenty of time to become ingrained with a host of societal norms. I am not convinced that docile behavior is what's best for us as scholars, teachers, or leaders in society.

This initiation process also sifts out or "normalizes" non-white or non-male faculty. If we are to be accepted-i.e., receive tenure-then we must conform to norms set by people different from us. We must, in effect, normatively become white males to some extent, if we are to achieve this form of approval. The extent to which this is necessary, in my experience, depends partly on the institution.

If the profession really wants to practice something like affirmative action, we must expect and accept difference. We will, at the same time, be expecting and accepting innovation. As Frank Zappa put it, "Without deviation from the norm, progress is impossible."

If tenure is really going to be used to protect free speech, it must be routinely granted to a wider group of people than in the past. It must be granted to those who are "different" in some respect from the current professional norms, rather than being held out as a carrot that encourages docility and conformity. As the system currently operates, the hope of achieving tenure actually stifles free speech.

Lilias Jones
South Dakota State University

\section{Tenure Talk II}

My opposition to tenure stems from my firm conviction that it works to subvert the very purpose of higher education - teaching students. I recall the very worst teachers from my own undergraduate education fell in one of two categories. Either they were the most senior professors who were stale and intellectually dead, or they were inexperienced, temporary faculty with no stake in doing their best. I vividly recall one diplomatic historian who read his typed notes in a monotone accomplishing the extraordinary feat of making European diplomatic history from 1870-1914 boring. Quite an accomplishment considering the subject included the fascinating diplomacy of Bismarck-that master of realpolitik. I also recall a teacher in a freshman literature course who routinely failed to show up for lecture on Fridays. The habit was especially non-endearing to students since the class met from 4 to 5 PM. To the extent that colleges are top heavy with senior, tenured faculty, they are forced to use greater numbers of temporary faculty ending up with more teachers of the worst sort.

Meanwhile, the attractiveness of academic life - with its unstructured time tantamount to 18 weeks of paid vacation a year-drives a growing numbers to the profession. Tenure relieves senior faculty of any pressure to perform since annual evaluations offer only slight monetary incentives. In some cases the monetary reward for excellent performance might be as little as $\$ 400.00$ a year. That sum is not even a lot of money where I come from!

Thus academia is quite the contrast with other professions where the rigors of the job increase as one gains in responsibility providing senior people with real incentive to retire when the time comes. One of my senior colleagues captured the uniqueness of academia by noting 
that it allows "retirement while working". In such circumstances it is no wonder that there is an excess supply of new Ph.D.s despite the contracting job market. Since supply and demand for academics must be brought into closer balance something must be done about tenure. Marcia Lynn Whicker's suggestion for placing a limit on the number of years tenure is valid is an excellent one and should please both opponents and supporters of tenure. It would provide administrators some latitude and flexibility while protecting freedom of thought. In the end, students would be the beneficiaries.

\section{Janeen Klinger \\ Franklin \& Marshall College}

\section{Taking Exception}

The article, "The Electoral College: A Misunderstood Institution," that appeared in the March issue of $P S$ addresses purported inaccuracies about the Electoral College that are conveyed and perpetuated by textbooks in American government. My text, American Government in Action, is one of the books sampled in the piece.

As an author and scholar, I am certainly open to having my work scrutinized by my peers. Indeed, as a professional, I welcome the peer review process for assessing value, content, accuracy, and other related merits of scholarship. But I assume that such scrutiny will be conducted in an honest and fair manner by those carrying it out. It is in this light that I write to point out a gross misrepresentation of my work by Adkison and Elliott.

My text is mentioned in the article once, on p. 78. The relevant passage reads:

Several texts, however, imply that selection by state legislatures is the constitutionally mandated method. One text states, "they [the Framers] de- " signed a selection system of 'electors' chosen by state legislatures" (Berman and Murphy 1996, 70). Four texts (McKenna 1994, 517; Barrilleaux \{sic\} 1996, 49; Lineberry et al. 1991, 77; Lowi and Ginsberg 1996, 475) make this error....

In the case of my text, Adkison and Elliott's statement is grossly inaccurate. I checked the relevant citation in my book-and, indeed, all references to the Electoral College in that text-and confirmed that I made neither a direct statement nor an implication in any way consistent with what Adkison and Elliott claim.

To be specific, the passage in my text cited by the authors directly contradicts their claim. On p. 49 of American Government in Action I wrote:

$\ldots$ In the end, the Convention decided to create a new body of officials-the Electoral College-who would perform one function: to meet to select the president. The framers expected the Electoral College to serve as a body of eminent persons, selected by voters, who would assemble in each state to cast ballots for the president and vice-president. Electors would be allocated to each state on the basis of its representation in Congress. The process was intended to employ a kind of representative democracy in the choice of the chief executive, while making the president independent of other governmental officers. [Emphasis mine]

Please note that my text makes no claim whatsoever regarding what is constitutionally mandated. Nor does it claim or imply that state legislatures would choose electors. To the contrary, my text speaks of an expectation by members of the Constitutional Convention regarding the role of the Electoral College as an intermediary body between voters and the president.

I also found a problem in another source cited by Adkison and Elliot. Pulling a copy of Lowi and Ginsberg's text off my bookshelf, I could not find language to substaniate their claim. Indeed, Lowi and Ginsberg also assert that voters would choose electors.

There are two important issues here. One is honesty and accuracy in scholarship: it is ironic that an article purporting to clear up inaccuracies should itself engage in misrepresentation of authors. Second, those of us who write texts put our professional reputations on the line when we do so. I certainly have not sold enough books for money to be an issue, but I do have a reputation to protect. The authors-and PS-owe textbook authors the courtesy of getting their facts straight.

Ryan J. Barilleaux Miami University 